ROCZNIKI PEDAGOGICZNE

Tom 12(48), numer $4-2020$

DOI: https://doi.org/10.18290/rped20124-10

MARTA FILIPOWICZ

\title{
RUCH ATD CZWARTY ŚWIAT O. JÓZEFA WRZESIŃSKIEGO I JEGO PROGRAM INKLUZJI I INTEGRACJI SPOŁECZNEJ
}

\section{WPROWADZENIE}

Założyciel Ruchu ATD Czwarty Świat, ojciec Józef Wrzesiński, udzielił zaskakującej odpowiedzi dziennikarzowi, który zadał mu pytanie o początki tej działalności. Na pytanie „kiedy został założony Ruch ATD Czwarty Świat?” o. Wrzesiński powiedział: „kiedy miałem pięć lat” (Redegeld, 2011, s. 1). Czym zatem jest owy Ruch? Dlaczego został powołany? Czym się zajmuje? I wreszcie, co miał na myśli jego twórca kiedy wyjaśniał, że w chwili powstania Ruchu on sam miał 5 lat?

Celem artykułu jest prezentacja Ruchu ATD Czwarty Świat oraz przybliżenie jego głównych idei. Niniejszy artykuł będzie miał następującą strukturę: 1) rys biograficzny o. Józefa Wrzesińskiego; 2) geneza Ruchu ATD Czwarty Świat, również z uwzględnieniem biograficznych wątków jego założyciela; 3) główne działania Ruchu (cele, zadania i kierunek działalności); 4) polityka inkluzji i integracji społecznej z uwzględnieniem przesłania dla współczesnych działaczy na rzecz osób wykluczonych społecznie, ubogich i bezdomnych.

Podstawową metodą zastosowaną $\mathrm{w}$ artykule jest analiza literatury, którą stanowiły zarówno pozycje książkowe, jak i artykuły naukowe i popularnonaukowe. W tym miejscu warto dodać, że podjęta $\mathrm{w}$ niniejszym tekście tematyka nie jest powszechnie znana w Polsce. Istniejąca literatura jest dość uboga. Niemniej jednak niniejsza tematyka - w opinii autorki tekstu - jest warta podjęcia i poddania szerszej refleksji. Cenne wydaje się także ukaza-

Dr Marta FiliPowicz - Wydział Nauk Społeczno-Pedagogicznych w Katowicach, Wyższa Szkoła Pedagogiczna im. Janusza Korczaka w Warszawie; adres do korespondencji: ul. Katowicka 24, 40-173 Katowice, e-mail: m.filipowicz@wspkorczak.eu; ORCID: https://orcid.org/00000002-3315-6701. 
nie ponadczasowego przesłania pozostawionego przez ojca Józefa Wrzesińskiego, które dotyczy pracy z osobami doświadczającymi wykluczenia społecznego.

\section{RYS BIOGRAFICZNY O. JÓZEFA WRZESIŃSKIEGO}

Józef Wrzesiński urodził się 12 lutego 1917 r. w Angers we Francji ${ }^{1}$ jako drugie z czwórki dzieci Włodzimierza Wrzesińskiego, polskiego imigranta, i Lukrecji Wrzesińskiej (z domu Sellas), pochodzącej z Hiszpanii. Rodzina Józefa Wrzesińskiego doświadczała skrajnej biedy i wynikającego z tego stanu wykluczenia społecznego. Włodzimierz Wrzesiński, ojciec Józefa, jako posiadacz niemieckiego paszportu ${ }^{2}$ - co było jednoznaczne z tym, że był politycznie podejrzany - został w czasie wybuchu I wojny światowej internowany do fortu Saumur (Francja). Jako cudzoziemcy, politycznie internowani mieli utrudnioną możliwość podjęcia pracy zarobkowej, co przełożyło się na ich dalsze losy. Po skończonej wojnie Wrzesińscy zamieszkali w opuszczonej kuźni znajdującej się w dzielnicy miasta zamieszkiwanej przez najbiedniejszą społeczność ówczesnego Angers. Nasilające się kłopoty z brakiem pracy spowodowały, że Włodzimierz Wrzesiński porzucił rodzinę, więc Lukrecja podjęła się pracy zarobkowej polegającej na służbie u bogatych mieszkańców Angers.

W roku 1936 Józef Wrzesiński wstąpił do seminarium w Soissons. Wybuch II wojny światowej spowodował, że święcenia kapłańskie otrzymał dopiero 29 czerwca 1946 r., również w Soissons. Pierwsze 10 lat posługi kapłańskiej pełnił w wiejskiej parafii (w Tergnier). W 1956 r. dostał od biskupa Douillarda propozycję pracy w obozowisku dla bezdomnych w Noisy-le-Grand 15 km od Paryża. W dniu 14 lipca 1956 r. zamieszka1 w obozowisku pośród przebywających tam 252 rodzin, bezdomnych i żyjących w skrajnej biedzie. W roku 1957 o. Józef Wrzesiński wraz z bezdomnymi rodzinami z obozowiska Noisy-le-Grand założył stowarzyszenie „Aide

\footnotetext{
${ }^{1}$ Józef Wrzesiński znany jest za granicami Polski jako Joseph Wresinski. Rys biograficzny został opracowany na podstawie: A. de Vos van Steenwijk, Ojciec Józef Wrzesiński. ATD Czwarty Świat, Jedność: Kielce 2000, s. 7 i n.; http://dziedzictwo.ekai.pl/text.show?id=4658 (dostęp: 20.01.2020); http://www.atd.org.pl/?page_id=1652 (dostęp: 20.01.2020); https://www.josephwresinski.org/en/proces-beatyfikacyjny/ (dostęp: 05.02.2020).

${ }^{2}$ Włodzimierz Wrzesiński pochodził z Wielkopolski, w czasie kiedy emigrował na Zachód, podobnie jak tysiące jego rodaków, Poznań - miasto rodzinne - było zajęte przez Prusy (zob. Wrzesiński, 2000, s. 53).
} 
à Toute Détresse” (ATD) (tłum. „Pomoc wobec każdego nieszczęścia”) „Quatre Monde" (tłum. Czwarty Świat). W roku 1973 założył Międzynarodowy Ruch ATD Czwarty Świat. Natomiast w roku 1979 o. Wrzesiński został członkiem francuskiej Rady Ekonomiczno-Społecznej. Owocem pracy w radzie był opracowany raport dotyczącego ubóstwa, który 17 października 1987 r., w obecności około 100 tys. osób został przedstawiony na paryskim Trocadero. W treść niniejszego raportu zostały wpisane przez o. Wrzesińskiego postulaty o uznanie godności ubogich i ich praw w społeczeństwie. Ojciec Wrzesiński należał do jednych z pierwszych obrońców praw człowieka.

W dniu 14 lutego 1988 r., w wieku 71 lat o. Wrzesiński umiera w Mérysur-Oise (Val d'Oise), tam też zostaje pochowany (w miejscowości siedziby Międzynarodowego Centrum Ruchu ATD Czwarty Świat).

W roku 1992 ONZ ogłosiło dzień 17 października Międzynarodowym Dniem Walki z Ubóstwem (jest to data, która była wybrana przed 1992 r. przez Międzynarodowy Ruch ATD Czwarty Świat jako Światowy Dzień Sprzeciwu Wobec Nędzy) (de Vos van Steenwijk, 2000; O. Józef Wrzesinski; Ojciec Józef Wrzesiński).

Proces beatyfikacyjny o. Józefa Wrzesińskiego został otwarty w diecezji Soissons 19 marca 1997 r. i zakończony na szczeblu diecezjalnym w roku 2003. W dniu 2 czerwca 2007 r. Kongregacja do spraw Świętych na podstawie otrzymanej dokumentacji wydała dekret zatwierdzający (Wielcy świadkowie, 1987).

\section{GENEZA RUCHU ATD CZWARTY ŚWIAT}

We wstępie niniejszego tekstu została przywołana wypowiedź o. Wrzesińskiego dotycząca czasu powstania Ruchu ATD Czwarty Świat. Odpowiedź przenosi nas do roku 1922, to wtedy Józef Wrzesiński ma 5 lat. Co zatem wydarzyło się w życiu przyszłego duchownego, że w jego sercu zapisuje się pragnienie dokonania zmian w ówczesnym świecie? W książce pt. Ujrzyjmy stońce o. Wrzesiński przedstawia historię swego dzieciństwa (Wrzesiński, 2007). Opisuje, że wychowywał się w rodzinie doświadczającej skrajnego ubóstwa, a z tego powodu - wykluczenia społecznego. Tak ciężka sytuacja ekonomiczna i społeczna była spowodowana zawiłymi losami jego rodziców. W pierwszej części niniejszego tekstu został nakreślony kontekst historyczno-ekonomiczny rodziców Józefa Wrzesińskiego. Ten stan rzeczy 
mocno wpłynął i ukształtował życie Józefa, a także wymusił by ten, już jako dziecko, podjął się pracy zarobkowej na rzecz swojej rodziny. Już od wczesnych lat życia wykonywał obowiązki zawodowe, za które otrzymywał zapłatę $\mathrm{w}$ pieniądzach, jak również $\mathrm{w}$ różnych produktach spożywczych. Ponadto jako młody chłopiec był też świadkiem wielu sytuacji, w których jego matka Lukrecja Wrzesińska doświadczała szykan z tytułu swych trudnych warunków materialnych, on sam również nieraz był ich bezpośrednim odbiorcą. Po latach o tym okresie napisał: „kiedy miałem cztery lata, chodziłem paść kozę na okolicznych łąkach [...]. Prowadząc kozę na łąki, przechodziłem obok ogromnej bramy klasztoru Dobrego Pasterza, a wtedy jedna z zakonnic zagadywała do mnie czasem. Pewnego dnia zapytała, czy nie chciałbym codziennie rano służyć do mszy. I tego właśnie dnia zostałem po raz pierwszy w życiu zaangażowany do pracy" (Wrzesiński, 2007, s. 42). $\mathrm{Z}$ relacji o. Wrzesińskiego dowiadujemy się, że za tą - jak sam nazywał pracę otrzymywał: codziennie kubek kawy z mlekiem, chleb, konfiturę, natomiast $\mathrm{w}$ dni świąteczne masło, a także ziemniaki, soczewicę, czasem kilka kawałków mięsa. Zapłatą za codzienne stawianie się do służby jako ministrant - a co przesądziło o tym, że przez prawie jedenaście lat każdego ranka przemierzał długą ulicę św. Jakuba, a następnie ulicę Brault w kierunku klasztoru - była kwota w wysokości dwóch franków tygodniowo (Wrzesiński, 2007, s. 43). „Dzięki temu - wyjaśnia o. Wrzesiński - głód w naszej rodzinie mógł być jako tako zaspokojony" (Wrzesiński, 2007, s. 44). Jak dowiadujemy się z relacji Alwine de Vos van Steenwijk - jednej z najbliższych współpracownic o. Wrzesińskiego, współzałożycielki Międzynarodowego Ruchu ATD Czwarty Świat i autorki książki biograficznej o duchownym Józef Wrzesiński, pomimo swego młodego wieku, był na tyle świadomy ciężkiej sytuacji rodzinnej, że zaakceptował tę codzienną służbę i z oddaniem wykonywał swój obowiązek (de Vos van Steenwijk, 2013, s. 21). Wraz z upływem lat Józef Wrzesiński podejmował się kolejnych prac zarobkowych, takich jak: robienie różnego rodzaju sprawunków bogatszym mieszkańcom dzielnicy Angers, wykonywanie prac chałupniczych, zbieranie węgla w pobliżu miejskiej gazowni (Wrzesiński, 2007, s. 44; de Vos van Steenwijk, 2013, s. 21-22).

Gdzie zatem tkwił zasadniczy problem? Co miał na myśli o. Józef Wrzesiński mówiąc, że „założył” Ruch ATD Czwarty Świat już jako pięciolatek? Oczywiście nie dotknęliśmy najważniejszej sprawy, jaką jest skrajne ubóstwo i wykluczenie społeczne, którego doświadczała cała rodzina Wrzesińskich i jakie z tego faktu wynikało dla niej upokorzenie i wstyd. 
Ojciec Wrzesiński używa określenia „droga wstydu” i „droga poniżenia”, mówiąc o tym, jak wyglądało jego dzieciństwo. Określenia te mają znaczenie dosłowne - mowa tu jest o przemierzaniu drogi prowadzącej z domu do różnych miejsc, w których jako dziecko musiał świadczyć różnego rodzaju pracę zarobkową, a także - drugie znaczenie - metaforyczne, odwołujące się do jego mentalnego podejścia do niniejszych doświadczeń. Wrzesiński relacjonuje: „«droga poniżenia», która wymazała ze wspomnień mego dzieciństwa to, co mogło w nich być jako tako pocieszające [...]. «drogi wstydu», związane $\mathrm{z}$ dokuczliwym brakiem żywności [...]. Takie to były nieustanne upokarzające zmagania ludzi biednych, chcących nasycić swój głód" (Wrzesiński, 2007, s. 44). Wobec powyższego można wysnuć wniosek, że to doświadczenie wstydu i upokorzenia miał na myśli o. Wrzesiński, mówiąc o chęci przeciwstawienia się biedzie poprzez działania Ruchu, w celu zniwelowania nie tyle różnic materialnych (choć też ten aspekt był ważny), ale przede wszystkim przywrócenie godności osobom ubogim i uwolnienie ich od upokorzeń i poczucia wstydu.

Z biografii o. Józefa Wrzesińskiego - jak zauważa Elżbieta Tarkowska dowiadujemy się, że od samego początku swego kapłaństwa (święcenia przyjęte w 1946 r.) duchowny szukał służby w tych parafiach, które były najbardziej dotknięte ubóstwem. Trudno jednak wskazać, dlaczego został poproszony o objęcie opieką duszpasterską rodziny zamieszkujące w obozie dla bezdomnych znajdującym się około 15 km od Paryża. Obóz Noisy-leGrand charakteryzował się szczególnie trudnymi warunkami życia. Było to miejsce skupiające 252 rodziny żyjące w prowizorycznie zbudowanych barakach, bez infrastruktury sanitarnej, bez źródła utrzymania, wegetujących w skrajnej biedzie (Tarkowska, 2010, s. 18-21). Warto w tym miejscu oddać głos ks. Leonowi Bach - długoletniemu i wiernemu przyjacielowi ojca Wrzesińskiego - który relacjonuje: „Pojechałem do niego do Noisy-le-Grand. Było to dla mnie tak, jakbym zjawił się na księżycu. Były tam igloo (takiego terminu używano na określenie baraków zbudowanych z płyt azbestowych przypis M.F.) z ludźmi biednymi wszelkiego rodzaju. Nawet w baraku, gdzie on sam spał, umieścili gruźliczkę, która kasłała dzień i noc. Ja też tam spałem. Był to nędzny barak ze źle połączonych desek. Nie było ogrzewania [...]. Nie wyobrażałem sobie takiego kontaktu z nędzą [...]. Wiedziałem tam, że on robi naprawdę coś nadzwyczajnego" (de Vos van Steenwijk, 2013, s. 63). Ojciec Wrzesiński zamieszkujący razem z bezdomnymi w Noisy i uczestniczący w ich życiu wiedział, że „musi zacząć działać”. Sceny z życia w obozie (dramat bezrobocia, rozdzielanie dzieci od rodziców, 
przemoc, powszechne przygnębienie i apatia, brak nadziei) były motorem do powołania stowarzyszenia, które dało początek Ruchowi ATD Czwarty Świat (de Vos van Steenwijk, 2013, s. 63-66). I tak w roku 1957 zostaje założone stowarzyszenie, które „opierało się na partnerskich relacjach z biednymi i polegało na udziale najbiedniejszych w podejmowaniu na ich rzecz działań” (Tarkowska, 2010, s. 21). Ojciec Wrzesiński wspomina: „od początku istnienia naszego Ruchu decydujące było to, że nie mieliśmy nic do zaoferowania, jak tylko samych siebie. Niczego nie posiadaliśmy, nie byliśmy organizacją pożytku publicznego, ani pracownikami społecznymi zależnymi od jakiegoś urzędu. Mogliśmy służyć tylko naszymi osobami i sercami bijącymi w nas" (Wrzesiński, 2007, s. 51-52). Ruch ATD Czwarty Świat, czyli „Aide à Toute Détresse” (ATD) jest thumaczony jako „Pomoc wobec każdego nieszczęścia" i poprzez swą nazwę najmocniej wyjaśnia, jaki miał zakres swej działalności. Na zakończenie tej części warto jeszcze wyjaśnić dalszy człon nazwy, czyli „Czwarty Świat” (Quatre Monde). To określenie nawiązuje do dzieła „Kroniki stanu czwartego” (1789 r.) autorstwa Dufourny de Villiersa. Terminem „czwarty stan” określano „nędzarzy, najbiedniejszych wyrobników, niezdolnych do pracy ludzi kalekich" (Tarkowska, 2010, s. 15).

Jeśli geneza - jak podaje Słownik Polski - to „czynniki, które złożyły się na powstanie i rozwój czegoś" (Słownik Polski PWN, 2020) to w przypadku Ruchu ATD Czwarty Świat tymi czynnikami były: doświadczenia skrajnej biedy oraz chęć trwałej zmiany tej sytuacji. Ojciec Wrzesiński w wypowiedzi z okazji 20. rocznicy utworzenia Ruchu wyjaśnia, jakie były podwaliny powstawania stowarzyszenia. U podłoża powołania Ruchu był potrójny sprzeciw: „wobec nieuchronności ubóstwa; sprzeciw wobec obciążania winą tych, którzy cierpią ubóstwo; sprzeciw wobec marnotrawstwa duchowego i ludzkiego, spowodowanego przez to, że społeczeństwo tak łatwo obywa się bez doświadczenia tych, którzy żyją w ubóstwie" (Wrzesiński, 2007, s. 57). Zatem Ruch był głosem protestu: 1) przeciwko samemu ubóstwu (niezgodzie na jej występowanie, nawet w najmniejszej formie oraz pod każdą postacią); 2) przeciwko obwinianiu ubogich za stan, w jakim się znajdują; 3) przeciwko niekorzystaniu, czy odrzuceniu wiedzy o ubóstwie pochodzącej od samych ubogich.

Warto przejść do prezentacji głównych założeń Ruchu ATD Czwarty Świat i dać odpowiedź na rodzące się pytania: jaka była koncepcja tego stowarzyszenia? Jakie miało cele działań i w jaki sposób je realizowano? 


\section{GŁÓWNE ZAŁOŻENIA RUCHU ATD CZWARTY ŚWIAT}

Ruch na przestrzeni lat 1957-1973 dynamicznie rozwija się i rozrasta, a od roku 1973 zostaje przekształcony w Międzynarodowy Ruch ATD Czwarty Świat. Zaczynający lokalnie, zrzeszający tylko rodziny z obozu Noisy-le-Grand, wraz z upływem czasu zaczyna przenikać do ówczesnych struktur pomocowych, kulturowych, państwowych. Zawsze jednak (od samego początku swojego istnienia) koncentrował się na niesieniu pomocy osobom doświadczającym wykluczenia społecznego, które było konsekwencją ubóstwa. W centrum uwagi Ruchu były osoby bezdomne, bezrobotne, ubogie. Analizując dzieła pozostawione przez o. Wrzesińskiego, można wypunktować główne założenia Ruchu ATD Czwarty Świat. Poniżej, w zarysie zostaną opisane wiodące obszary działalności Ruchu. Na ten obraz zatem będą składały się:

1. „Obrona rodziny”. W tym haśle zamyka się nie tylko otoczenie troską i opieką rodziny, ale także przywrócenie jej należytego miejsca w społeczeństwie. Zatem walka o uznanie jej jako naturalnego i podstawowego środowiska wychowawczego;

2. „Obrona praw człowieka”. Ten postulat rozumiany jest jako obrona godności osoby ubogiej, doświadczającej wykluczenia społecznego i sprzeciwianie się szeroko rozumianemu łamaniu praw osoby ubogiej;

3. „Promocja kultury i edukacji”, która była rozumiana jako rozwój kultury i wspieranie nauki/edukacji w środowisku osób bezrobotnych, bezdomnych, ubogich. Działania prowadzone na rzecz edukacji zarówno dzieci, jak i osób dorosłych doświadczających ubóstwa i mających z tego powodu liczne utrudnienia w zdobywaniu odpowiedniego wykształcenia.

Warto zatem w tym miejscu odnieść się do wyżej wymienionych działań Ruchu ATD Czwarty Świat i nakreślić ich charakterystykę. W pierwszej kolejności przyjrzyjmy się działaniom dotyczącym obrony rodziny. Ojciec Wrzesiński wyjaśnia, że w momencie zakładania stowarzyszenia, opinia i zainteresowanie społeczne rodziną znacznie traciło na swojej popularności. Wrzesiński podaje: „organizacje społeczne i publiczne służby społeczne nigdy do końca nie zrozumiały, dlaczego poświęcamy szczególną uwagę rodzinie. Dlaczego tak bardzo nam na niej zależy? [...] Ponieważ podkreślaliśmy znaczenie rodziny, zawsze uważano nas za należących do przeszłości, a my, choć bardzo cierpieliśmy $z$ tego powodu, byliśmy niezachwiani" (Wrzesiński, 2007, s. 51). Czym zatem dla o. Wrzesińskiego była rodzina? Jak argumentował jej obronę i dlaczego ją afirmował? 
Rodzina była dla o. Wrzesińskiego odbiciem Świętej Rodziny. To wymowne porównanie zostało uczynione w książce Żyć Ewangelia w rodzinie. Z jej treści możemy dowiedzieć się, że każda rodzina (także ta mieszkająca w obozowisku Noisy-le-Grand) jest odbiciem tej rodziny, w której urodził się Pan Jezus (Wrzesiński, 2000, s 14-15; 33-40). Ojciec Wrzesiński wyjaśnia: „chciałbym podzielić z wami moje głębokie przekonanie, że wy, wszystkie rodziny, zgromadzone tutaj, jesteście kopią rodziny Jezusa" (Wrzesiński, 2000, s. 48). Wypowiedź ta była skierowana bezpośrednio do rodzin $\mathrm{z}$ obozu Noisy i zawierała w sobie zarówno definicję rodziny, jak i stojące przed nią zadanie do wykonania. Innymi słowy można powiedzieć, że z przytoczonych powyżej słów wynika, iż każda rodzina jest święta (co wynika z ustanowienia rodziny przez Boga Stwórcę) oraz że każda osoba powinna dążyć do uświęcania swej rodziny.

$\mathrm{Z}$ dalszych wypowiedzi dowiadujemy się, dlaczego duszpasterz walczył o rodziny, o ich uznanie i umacnianie w społeczeństwie. Jak sam wyjaśnia, rodzina jest „pierwszą grupą, w której dokonuje się nauka miłości, jest ona miejscem, gdzie zapada postanowienie życia w miłości, podejmowana jest decyzja tworzenia nowego życia, gdzie rodzą się kobiety i mężczyźni, którzy są zdolni kochać w następnej kolejności" (Wrzesiński, 2000, s. 26). Z przytoczonego cytatu możemy wywnioskować, że rodzina to nie tylko struktura społeczna, ale przede wszystkim szkoła życia i miłości.

Ojciec Wrzesiński wartość rodziny podkreślał nie tylko słowem, ale przede wszystkim licznymi działaniami prowadzonymi na jej rzecz. Warto zatem przedstawić konkretne akcje, które miały miejsce w obozowisku Noisy-le-Grand i były wyrazem walki o rodzinę. Do tych działań należy zaliczyć:

- przeciwdziałanie rozdzielaniu dzieci od rodziców. Mowa tu jest o wszystkich tych sytuacjach, w których rodzice byli pozbawiani praw rodzicielskich tylko z powodu złej sytuacji materialnej. Wrzesiński uważał, że nie wolno dopuszczać do sytuacji pozbawiania praw rodzicielskich rodziców, którzy są bezrobotni (Wrzesiński, 2007, s. 69), ubodzy, doświadczający trudnych sytuacji życiowych (de Vos van Steenwijk, 2013, s. 163164). Stanowczo protestował przy każdorazowej próbie rozdzielania rodzin mieszkających w Noisy-le-Grand (de Vos van Steenwijk, 2013, s. 99), a gdy miały miejsce te trudne sytuacje mocno je przeżywał i cierpiał $z$ tego powodu (de Vos van Steenwijk, 2013, s. 66). Głosił, że rodzina zawsze powinna być wspierana, umacniana. Wyznawał pogląd, że rodzina jest wspólnotą, która nie powinna być rozdzielana. To silne stanowisko w tej sprawie 
miało swe korzenie w doświadczeniach z lat dziecięcych. Tu warto wspomnieć, że o. Wrzesiński obserwował i uczył się od swej matki, Lukrecji, walki o nierozerwalność wspólnoty rodzinnej. W jednym $\mathrm{z}$ wywiadów wyjaśnia: „W pewnym okresie naszego życia byliśmy tak biedni, że zaproponowano mej matce, by oddała mnie do sierocińca w Auteuil" (Wielcy świadkowie, 1987). Z dalszej wypowiedzi dowiadujemy się, że spotkało się to z dużym protestem ze strony jego matki. Duchowny stwierdził, że jego matka była osobą dumną, znającą wartość swoją i swojej rodziny (Wielcy świadkowie, 1987), a także znająca swoją rolę jako matki, jej obowiązków wobec swych dzieci i odpowiedzialności za rodzinę (de Vos van Steenwijk, 2013, s. 2021). Dlatego ten postulat działalności Ruchu ATD Czwarty Świat, jakim było przeciwdziałanie rozdzielaniu dzieci od rodziców, był realizowany także poprzez umacnianie więzi rodzinnych. A nie mogłoby to odbywać się bez wiedzy o kondycji duchowo-materialnej rodzin zamieszkujących w obozowisku Noisy-le-Grand. Ojciec Wrzesiński znał codzienne troski i kłopoty rodzin z obozu dla bezdomnych i wiedział, jak stawić im czoła (Wrzesiński, 2007, s. 25-27);

- zakładanie przedszkoli w obozowisku Noisy. Warto dodać, że w opinii o. Wrzesińskiego przedszkola spełniają nie tylko funkcję opiekuńczo-wychowawczą, ale dają realną możliwość umacniania rodzin i przeciwdziałania rozdzielania dzieci od rodziców doświadczających ubóstwa. Taką intencję zdradza podtytuł cytowanej powyżej książki A. de Vos van Steenwijk. Wymowny podtytuł, który brzmi „,...] przedszkole zamiast rodzin zastępczych” wyjaśnia, że namacalną pomocą dla rodzin jest zakładanie w miejscu zamieszkiwania ubogich rodzin przedszkoli (de Vos van Steenwijk, 2013, s. 72-73);

- sprzeciw wobec prawa, które przeszkadza rodzinom żyjącym w biedzie „brać na siebie odpowiedzialność rodzinną” (Wrzesiński, 2007, s. 54). Mowa jest tu o walce z prawem, które czyni z rodziców przedmiot działań pomocy społecznej oraz traktuje ich jako niezdolnych do odpowiedzialności za swoje rodziny. To także krytyka takiego prawa, w myśl którego odbiera się prawo rodzica do jego dziecka. O konsekwencjach takiego postępowania o. Wrzesiński pisał: „w imię jakiejś sprawiedliwości przywłaszczamy sobie nawet jego rolę ojca, zastępujemy go w stosunku do jego dzieci; uznajemy, że nie wypełnia swoich obowiązków i wydajemy na niego wyrok. W ten sposób nigdy już nie będzie prawdziwym ojcem, w pełni odpowiedzialnym za swoją rodzinę i broniącym jej praw" (Wrzesiński, 2007, s. 107-108). 
Z powyższego opisu wynika, że Ruch ATD Czwarty Świat skupiał się na całościowej, kompleksowej pomocy rodzinie. Można zaobserwować, że rodzina była w centrum działań o. Wrzesińskiego. Szereg działań podejmowanych na rzecz rodzin doświadczających skrajnego ubóstwa oscylował wokół umacniania jej i wspierania.

Drugi obszar działań, jaki można zaobserwować w ramach funkcjonowania Ruchu ATD Czwarty Świat, to szeroko rozumiana obrona praw człowieka. Ojciec Wrzesiński relacjonuje: ,jedynym naszym celem był człowiek i działanie na jego rzecz" (Wrzesiński, 2007, s. 52). Warto dodać, że ten obszar ściśle wiązał się z powyższym, czyli z obszarem walki o rodzinę. Sam o. Wrzesiński podkreślał, że walczył z traktowaniem rodzin ubogich jako przedmiotu działań i kontroli (Wrzesiński, 2007, s. 76) oraz traktowaniem ich jako podopiecznych i ,ludzi niezdolnych do usamodzielnienia się" (de Vos van Steenwijk, 2013, s. 61).

Należy w tym miejscu wyjaśnić, że o. Wrzesiński reprezentował stanowisko zbudowane na takiej koncepcji człowieka, która przyjmuje, że każdy człowiek - niezależnie od stanu posiadania i zasobów dóbr materialnych jest obdarzony niezbywalną godnością, a wszelka próba odbierania tej godności jest łamaniem jego podstawowych praw. Dlatego walka z ubóstwem stała się walką o obronę godności, a obrona godności osób ubogich ukierunkowała działania Ruchu ATD Czwarty Świat na działania zmierzające do upominania się o respektowanie Praw Człowieka (Wrzesiński, 2007, s. 80-90).

Odnosząc się do tej kwestii, warto przywołać wypowiedź bezpośredniego uczestnika prowadzonej przez o. Wrzesińskiego działalności na rzecz walki o uznanie godności osób ubogich. Spośród wielu wspomnień i relacji osób znających i współpracujących $\mathrm{z}$ o. Wrzesińskim wybrałam tę wypowiedź, która nie tylko przybliża działalność, ale także obrazuje sposób, w jaki duchowny realizuje swoje cele. Świadek relacjonuje: ,ja osobiście doceniłem Ojca Józefa, jak papież przyjechał do Lionu. Ktoś jeden tylko mógł do niego mówić. Ojciec Józef wziął mnie pod rękę: «To ty będziesz mówił». Ja powiedziałem: «Nie, to jest raczej księdza miejsce». Odpowiedział mi: «Czwarty Świat to nie ja, to wy wszyscy. To wszyscy ludzie tacy jak ty, stworzyli Czwarty Świat. Ja nic nie zrobiłem». Więc to ja przedstawiałem Czwarty Świat papieżowi. A wtedy byłem w nędzy i już nie wierzyłem w Boga. To ciągle do mnie wraca. To jest fantastyczne. Ojciec Józef przeczuwał przyszłość. Wiedział, że nieszczęśliwi nie mogą tak pozostać. Zobaczcie, wszystko to, co on mi dał, to nie pieniądze, (to - M.F.) coś więcej. Pokazał mi, że jestem człowiekiem, że mam możliwości i że muszę z tego 
wyjść" (de Vos van Steenwijk, 2013, s. 132). Z przywołanej wypowiedzi można wyciągnąć wnioski, że jednym ze sposobów działania mającego na celu walkę o godność osób ubogich to uświadamianie samym ubogim, że mają godność, że ich godność jest taka sama jak godność osób należących do społeczeństwa pozostającego na wyższym poziomie ekonomicznym i społecznym.

Tu warto przejść do kwestii dotyczącej obrony godności osób ubogich, która rozgrywała się w przestrzeni ówczesnej pomocy socjalnej, a dokładniej rzecz ujmując, odnoszącej się do podejścia osób tę pomoc świadczących. Z licznych wypowiedzi o. Wrzesińskiego można stwierdzić, że szczególna uwaga została zwrócona na formę niesienia pomocy osobom zamieszkującym obóz Noisy-le-Grand.

Ojciec Wrzesiński zaobserwował, że nie tylko godność osób ubogich nie jest respektowana, ale także zagrożona jest ich wolność. Tłumaczył, że poprzez źle rozumiane udzielanie pomocy biednym zamieszkującym obóz Noisy-le-Grand została w znacznym stopniu ograniczana wolność osób korzystających z niniejszej pomocy. Mowa tu jest o uzależnieniu biednych od banków żywności, rozdawania posiłków (Wielcy świadkowie, 1987). Jak wyjaśnia tę kwestie Tarkowska - w obozie Noisy-le-Grand działało aż 27 organizacji zajmujących się działalnością dobroczynną, co w opinii o. Wrzesińskiego, czyniło z obozowiska „plac publiczny dla działań charytatywnych" (Tarkowska, 2010, s. 21-22), a to wpływało na ograniczenie odpowiedzialności i wolności osób tam mieszkających. Ojciec Wrzesiński nie był przeciwnikiem dobroczynności. Doceniał ją i pochwalał. Jednak upatrywał wielką szansę na wyjście z ubóstwa nie w darmowym rozdawnictwie, a w postrzeganiu osób ubogich jako tych, którzy mają prawo decydować o sobie, o swoich rodzinach i brać za swe życie odpowiedzialność.

Czyniąc podsumowania tego obszaru działań Ruchu ATD Czwarty Świat, warto dodać, że głównym źródłem upominania się o godność osób ubogich jest przekonanie, że każdy człowiek niezależnie od pozycji społecznej, zasobów materialnych jest dzieckiem Bożym i jest kimś niezbędnym w królestwie Bożym (Wrzesiński, 2010a, s. 36), kimś, bez kogo nie można mówić o pełni wspólnotowej.

Trzeci obszar działań prowadzonych przez Ruch ATD Czwarty Świat można określić stwierdzeniem „kultura orężem w walce z nędzą” (de Vos van Steenwijk, 2013, s. 73). W tym haśle zamyka się szereg akcji prowadzonych na rzecz polityki inkluzji. Jak zatem o. Wrzesiński za pomocą kultury walczył ze skrajnym ubóstwem? Już od początku działalności duszpasterskiej w obozowisku Noisy dążył do popularyzacji kultury wśród ubogich 
i bezdomnych. W pierwszych latach posługi w tym miejscu otrzymał pozwolenie na wybudowanie kaplicy. Wówczas za pośrednictwem swych przyjaciół zlecił wykonanie witraży, które zaprojektował Jean Bazaine, jeden z najwybitniejszych artystów francuskich (Wrzesiński, 2000, s. 67). Ojciec Wrzesiński stał na stanowisku, że kultura odgrywa „kluczową rolę w procesie przemiany społeczeństwa" (Wrzesiński, 1987, s. 4) i to poprzez kulturę może nastąpić zmiana i przemiana. Dlatego odrzucał system polegający na zależności osoby ubogiej od opieki socjalnej, a wprowadzał nowatorski program polegający na tworzeniu tzw. miejsca dzielenia się wiedzą (był to program pivots cultures, polegający na tworzeniu sytuacji umożliwiających rozwój kulturalny dzieci, poprzez np. zajęcia artystyczne, taniec, czytanie książek) oraz zakładanie ośrodków kultury (de Vos van Steenwijk, 2013, s. 101-102). Ojciec Wrzesiński uważał, że kultura jest narzędziem wolności (Wrzesiński, 1987, s. 1), a jeśli do osób pozostających w sferach skrajnego ubóstwa dociera tylko „wybrakowana część kultury”, natomiast sami ubodzy nie posiadają odpowiednich środków do odczytywania i czynienia jej spójną, konstruktywną i wyzwalającą (Wrzesiński, 1987, s. 1-2), nie mają możliwości doświadczania pełnej wolności, wynikającej z pełnego uczestnictwa w kulturze.

Promocja kultury stawała się zatem dla o. Wrzesińskiego walką z ubóstwem i wykluczeniem społecznym, które wynikało z ograniczonego kontaktu z kulturą. Za pośrednictwem kultury duchowny chciał znieść granice dzielące świat ubogich i świat osób pozostających na zadowalającym poziomie ekonomiczno-społecznym.

Orężem w tej walce była też promocja wiedzy, dlatego w roku 1968 - jak nadmienia Elżbieta Tarkowska - o. Wrzesiński tworzy wraz ze studentami program pt. „wiedza na ulicę”. Był to „program udostępniania wiedzy i kultury dzieciom z najbiedniejszych rodzin, którego celem było stwarzanie im możliwości rozwoju poprzez zajęcia artystyczne, organizację bibliotek, przedszkoli, wspólne czytanie książek" (Tarkowska, 2010, s. 22). Następnie tworzy biblioteki podwórkowe (nazywane też bibliotekami ulicy i pola) mające na celu dotarcie $\mathrm{z}$ wiedzą $\mathrm{w}$ centrum środowisk, w których przebywają ubodzy (Wrzesiński, 2010b, s. 82). Wrzesiński zauważał problem ubogiego dziecka pozbawionego możliwości edukowania się, zdobywania wiedzy, a tym samym zawodu (Wrzesiński, 2007, s. 69). W opinii o. Wrzesińskiego jednym z powodów ubóstwa jest brak wykształcenia, które nie tylko umożliwia podjęcie pracy zarobkowej, ale także daje szansę na nawiązywanie przyjaźni i budowanie solidarności z innymi, wyposaża w umiejętność wypowiadania się i zrozumienia funkcjonowania otaczającego świata (Wrzesiń- 
ski, 2007, s. 59). Wrzesiński wyjaśniał, że jest wielką krzywdą, jeśli „dzieci, które dlatego tylko, że pochodzą z ubogich rodzin, są zepchnięte na margines przez system szkolny, co powoduje, że stają się analfabetami, bez możliwości wyuczenia się zawodu" (Wrzesiński, 2007, s. 69). Duchowny dodawał: „dramatem ubóstwa jest to, że od samego dzieciństwa, dziecko czuje się na uboczu, nawet w szkole, nawet w obrębie szkolnym" (Wielcy świadkowie, 1987). Szansą na wyjście z tego kręgu ubóstwa jest szerokie i kompleksowe działanie, mające na celu promocję wiedzy i dostępu do edukacji.

W obronie swego stanowiska pisze: „myślenie i wiedza to rodzaj aktywności, do której zdolny jest każdy człowiek, niezależnie od posiadanej zdolności i doświadczenia. Każdy stara się poznać i zrozumieć rzeczywistość po to, aby zrealizować własny cel. Ponieważ myślenie nakierowane jest na cel, każda myśl może stać się aktem osobistego wyzwolenia. Opierając się na swoich doświadczeniach w różnych obszarach ubóstwa, Ruch ATD Czwarty Świat może zaświadczyć, że każda osoba i każda grupa nosi w sobie taki potencjał, niezależnie od tego jak skromne ma zdolności myślenia i analizy. Każdy człowiek i każda grupa poszukuje zrozumienia siebie i swojej sytuacji po to, aby panować nad swoim przeznaczeniem, zamiast poddawać mu się z lękiem" (Wrzesiński, 2010, s. 7-8).

Na zakończenie tej części tekstu można powtórzyć za Tarkowską, że „Ojciec Wrzesiński ogromną rolę $\mathrm{w}$ walce $\mathrm{z}$ ubóstwem przypisywał kulturze" (Tarkowska, 2010, s. 22), widział bowiem w niej szansę na społeczną równość.

\section{INKLUZJA I INTEGRACJA SPOŁECZNA}

Jedną z nowych propozycji na rynku polityki inkluzji i integracji społecznej była idea wybrzmiewająca w haśle „Wiedza pochodząca od osoby ubogiej i wykluczonej społecznie" (Wrzesiński, 2010b, s. 3-13). Ojciec Wrzesiński zaproponował odważny i innowacyjny sposób walki z ubóstwem. Mowa tu o wsłuchiwaniu się $\mathrm{w}$ głos tych, których dotyczy problem wykluczenia społecznego. Tak o tym mówi: „pragnęlibyśmy dać ludziom najuboższym możliwość zabrania głosu, tak aby mógł on zostać usłyszany, i aby rozmawiali z nimi w następujący sposób: «Słuchaj, jesteś ciekawym człowiekiem, przyjdź do nas i usiądź przy stole. Prosimy, zajmij miejsce między nami, ono należy do ciebie. Twoje poczucie sprawiedliwości, równości, twoja wiedza i doświadczenie życiowe są czymś, czego my nie posiadamy. Chodź z nami, potrzebujemy ciebie». To właśnie w tym i tylko w tym tkwi cały sens naszej 
walki: pragniemy dać miejsce pewnej społeczności i sprawić, aby jej doświadczenie miało znaczenie dla wszystkich ludzi" (Klein, 2011, s. 5).

Do takich samych wniosków dochodzi M. Jarmuszczak, która wyjaśnia, że „Wrzesiński pokazuje, że zwalczyć wykluczenie można tylko poprzez wprowadzenie ekspertyzy i głosu najuboższych do debaty publicznej, która ich dotyczy. Rezygnując z uczestnictwa osób, które znalazły się w niedoli, społeczeństwo pozbawia się niezwykle ważnej wiedzy o sobie samym, zbyt łatwo rezygnuje z tego, co mogłoby je wzbogacić" (Jarmuszczak, 2014, s. 171).

Kolejną ważną sprawą jest budowanie relacji między osobami ubogimi a społeczeństwem pozostającym na dobrym poziomie ekonomicznym. Tak o tej kwestii mówił o. Wrzesiński: ,jeśli nie uda się nam nawiązać z osobami najuboższymi relacji przyjaźni, a więc zbudować z nimi wspólnoty, ciągle będziemy sobie zadawali pytanie, czy aby nasze wysiłki nie są kompletnie chybione” (Klein, 2011, s. 3). Wrzesiński kontynuuje: „Ci ludzie odważą się rozmawiać z nami szczerze i otwarcie o swoich problemach tylko wówczas, jeśli będziemy pragnęli się dowiedzieć, co oni naprawdę przeżywają w głębi duszy i w jaki sposób interpretują swoją sytuację, jak widzą możliwość okazania sobie wzajemnie pomocy, i w jaki sposób budzi się w nich wiara i przekonanie, że razem z drugim człowiekiem są w stanie wydobyć się z położenia, w jakim się znajdują" (Klein, 2011, s. 3).

Istotnym elementem polityki inkluzji $\mathrm{i}$ integracji była walka o rodzinę, o jej tożsamość i miejsce w społeczeństwie (o czym szerzej była mowa w powyższym podrozdziale). Jak słusznie zauważa A. de Vos van Steenwijk, dla o. Wrzesińskiego ,polityka przeciw ubóstwu musi być polityką na rzecz rodzin (de Vos van Steenwijk, 2013, s. 99). Ojciec Wrzesiński już w roku 1964 apelował o zjednoczenie wszystkich sił wokół rodziny (de Vos van Steenwijk, 2013, s. 99). Nawoływał do otoczenia jej troską i pomocą, która umożliwi jej usamodzielnienie się i pełne uczestniczenie w społeczeństwie. Polityka inkluzji to też zmiana kierunku relacji pomiędzy odbiorcą pomocy socjalnej a świadczącym pomoc socjalną. Tu o. Wrzesiński podkreśla, że należy spojrzeć na rodziny ubogie jako te, które mają coś do zaoferowania i do przekazania społeczeństwu. Jako te, które posiadają wiedzę i w dodatku jako te, których wiedza jest potrzebna reszcie społeczeństwa.

\section{ZAKOŃCZENIE}

$\mathrm{Na}$ zakończenie prowadzonych rozważań warto wskazać te aspekty działalności prowadzone w ramach Ruchu ATD Czwarty Świat, które świadczyły 
o oryginalności programu walki z ubóstwem. Bez wątpienia tym, co uczyniło wyjątkowym zaproponowany przez o. Józefa Wrzesińskiego Ruch ATD Czwarty Świat, było czerpanie wiedzy od samych osób ubogich. To uwzględnienie ich doświadczeń, spostrzeżeń, wiedzy dało możliwość sprawnego i odpowiedniego świadczenia pomocy rodzinom zamieszkującym w obozie Noisy-le-Grand.

Kolejny aspekt, który należy podkreślić, to walka o rodzinę. Ojciec Wrzesiński mówi: „na czym polegała nasza oryginalność? Gdy zaczął się Ruch ATD Czwarty Świat, społeczeństwa były pewne siebie, wszyscy myśleli, że postęp w dziedzinie pomocy społecznej zlikwiduje nędze automatycznie i nieodwracalnie, wszyscy byli pewni zwycięstwa" (Wrzesiński, 2007, s. 51). Jednak tak się nie stało. Dlaczego? W opinii o. Wrzesińskiego zapomniano o jednym ważnym aspekcie, jakim jest rola rodziny i postrzeganie jej jako całości, jako wspólnoty. Ojciec Wrzesiński ukazywał siłę tkwiącą w rodzinie, podkreślał także, że w rodzinie znajdujemy, odkrywamy i umacniamy swoją tożsamość, a także w rodzinie uczymy się wolności (Wrzesiński, 2007, s. 51) tak potrzebnej do wychodzenia z ubóstwa.

Ojciec Wrzesiński stwierdził: „nędza jest nie tylko największą niszczycielką człowieka, absolutnie niemożliwą do zaakceptowania i niepojęta. Jest zbrodnią przeciw ludzkości, hańbą i zapomnieniem człowieka" (Wrzesiński, 2010a, s. 170). Dlatego należy dołożyć wszelkich starań, aby żaden człowiek nie cierpiał $\mathrm{z}$ jej powodu.

\section{BIBLIOGRAFIA}

DE Vos van SteEnwiJK, A. (2000). Ojciec Józef Wrzesiński. ATD Czwarty Świat. Kielce: Jedność.

de Vos van SteenwiJk, A. (2013). Ojciec Józef Wrzesiński. Rzecznik najbiedniejszych. Kielce: Jedność.

JARMUSZCZAK, M. (2014). Wykluczenie społeczne oczami filozofa i aktywisty - Jan Patočka i o. Józef Wrzesiński. Studia Philosophiae Christianae, 50(3), 159-176.

KLEIN, F. (2011). ATD Warszawa - teksty Józefa Wrzesińskiego (s. 1-8), https://www.joseph-wre sinski.org/wp-content/uploads/sites/3/2016/09/Refleksja_2011_-_4_teksty_Wrzesinskiego.pdf (dostęp: 05.02.2020).

O. Józef Wrzesiński, http://dziedzictwo.ekai.pl/text.show?id=4658 (dostęp: 20.01.2020).

Ojciec Józef Wrzesiński, http://www.atd.org.pl/?page_id=1652 (dostęp: 20.01.2020).

Proces beatyfikacyjny, https://www.joseph-wresinski.org/en/proces-beatyfikacyjny/ (dostęp: 05.02.2020).

Redegeld, H. (2011). Stały wolontariat ATD: solidarność z najuboższymi (s. 1-7). http://www. atd.org.pl/wp-content/uploads/2015/05/Historia-Ruchu-ATD.pdf (dostęp: 04.02.2020). 
Stownik Polski PWN (2020). https://sjp.pwn.pl/ (dostęp: 05.02.2020).

TARKowska, E. (2010). Ojciec Józef Wrzesiński i nowa socjologia ubóstwa. Kultura i Społeczeństwo, 54(3), 15-29.

Wielcy świadkowie naszych czasów. Spotkanie z Ojcem Józefem Wrzesińskim. La Vie. Rozmowa z France de la Garde. (1987). https://www.joseph-wresinski.org/wp-content/uploads/sites/ 3/2016/09/Wielcy_swiadkowie_OJW.pdf (dostęp: 04.02.2020).

WrZESIŃSKI, J. (1987). Świat kultury a świat biedy (s. 1-5). https://www.joseph-wresinski. org/wp-content/uploads/sites/3/2016/09/wiat_kultury_a_wiat_biedy.pdf (dostęp: 05.02.2020).

WrZESIŃSKI, J. (2000). Żyć Ewangelia w rodzinie. Kraków: Wydawnictwo WAM.

WrZESIŃSKI, J. (2007). Ujrzymy stońce. Pisma i słowa. Warszawa: Więź.

Wrzesiński, J. (2010a). Ubodzy. Bóg pośród nas, tłum. D. Samsel. Poznań: „W drodze”.

WrZesiŃSKI, J. (2010b). Wiedza prowadząca do działania. Kultura i Społeczeństwo, 54(3), 3-13.

\section{RUCH ATD CZWARTY ŚWIAT O. JÓZEFA WRZESIŃSKIEGO I JEGO PROGRAM INKLUZJI I INTEGRACJI SPOŁECZNEJ}

\section{STRESZCZENIE}

Artykuł opisuje Ruch ATD Czwarty Świat założony w 1957 r. przez o. Józefa Wrzesińskiego wraz z rodzinami zamieszkującymi obóz dla bezdomnych Noisy-le-Grand (pod Paryżem). W tekście został przedstawiony Ruch jako propozycja inkluzji i integracji społecznej oraz została zaprezentowana geneza Ruchu i jego główne założenia i cele.

Problem wykluczenia społecznego jest stale aktualny we współczesnym świecie i pomimo wielu działań prowadzonych w obrębie badanego tematu niestety jest kwestią jeszcze dość powszechną. Utworzony przez o. Wrzesińskiego Ruch ATD Czwarty Świat pokazuje nowy kierunek działań na rzecz zniwelowania szeroko rozumianego wykluczenia społecznego.

Słowa kluczowe: o. Józef Wrzesiński; ubóstwo; inkluzja; integracja społeczna; godność.

\section{THE ATD FOURTH WORLD MOVEMENT BY FATHER JOSEPH WRESINSKI AND HIS PROGRAM OF INCLUSION AND SOCIAL INTEGRATION}

\section{SUMMARY}

The article describes the ATD Fourth World Movement founded in 1957 by Father Joseph Wresinski with families living in the Noisy-le-Grand homeless camp (near Paris).The text presents the Movement as a proposal of social inclusion and integration, and presents the origin of the Movement and its main assumptions and goals.

The problem of social exclusion is still topical in the modern world and despite many activities carried out within the studied topic, unfortunately it is still quite common. The ATD Fourth World Movement, created by Father Wresinski, shows a new course of action to eliminate broadly understood social exclusion.

Keywords: Father Joseph Wresinski; poverty; inclusion; social integration; dignity. 